Conference paper (Preliminary communication)

UDC: 001.895:711.4

https://doi.org/10.18045/zbefri.2019.2.801

\title{
Smart city label: past, present, and future ${ }^{* 1}$
}

\author{
Primož Pevcin ${ }^{2}$
}

\begin{abstract}
Smart city concept or label has become increasingly popular in scientific literature as well as in contemporary urban policy-making, where it has been popularized for the purpose of solving complex urban problems. This paper focuses on the review of the existing literature on this concept, following mainly manifest content analysis approach. The scrutinisation process reveals that this concept has been indeed popularized recently, overtaking (and substituting) some more older concepts, which could be partly contributed to its terminological neutrality and broader content that it tries to address. However, the main practical impetus for the growth of popularity can be attributed to the technology push. The increase in the volume of research partially also reflects the availability of research funds, thus indicating that smart city investigation is also policy-driven topic. Following a trajectory, a potential for the new city label emergence in the future should not be disregarded.
\end{abstract}

Key words: smart city, sustainable city, city branding, urban policy-making

JEL classification: $031, \mathrm{H} 83$

\section{Introduction}

Smart city concept has become increasingly popularized in literature and in urban policy-making, as a response for the purpose of solving complex urban problems (like, e.g., social cohesion, environmental sustainability, economic recovery etc.) and is also often politically promoted for local electoral purposes (Nesti, 2018). One of the reasons for this lies in the increasing urbanization, where cities around the globe are, on the average, growing rapidly, although we can observe and must

\footnotetext{
* Received: 01-06-2019; accepted: 17-12-2019

1 The author acknowledges the financial support from the Slovenian Research Agency (research core funding No. P5-0093).

2 Associated Professor, University of Ljubljana, Faculty of Public Administration, Gosarjeva ulica 5, SI-1000 Ljubljana, Slovenia. Scientific affiliation: public management, multi-level governance, localself-government.Phone: +386_1_5805_584.E-mail:primoz.pevcin@fu.uni-lj.si.
} 
also acknowledge the existence of reverse processes on some occasions (see, e.g., Zingale et al., 2017), but the former trend is prevailing. This creates large challenges on environment, sustainability and governance that cities need to cope with (World Cities Report, 2016). Namely, more than half of world's population now live in urban areas, and we can observe growth of cities, and them becoming in some instances megacities, which generates economic, social and physical problems, steaming also from multiple and diverse stakeholders and socio-political complexity of this large units (Chourabi et al., 2012).

The result of this pressures is that city administration often make proclamations on their smartness. In order to put some evidence on it, smart solutions, either technological or softer, are targeted. This often occurs also through policy pressures that receive a lot of sponsorship. This is also reflected in the increasing amount of scientific literature produced on the topic of smart city in recent years. In this context, this paper focuses on the review of the existing literature on the concept of smart city, following manifest and latent content analysis approaches. The main research questions that wanted to be addressed are: (1) what has contributed to the growth of the literature on the smart cities; (2) are there any potential patterns related to the frequency of appearance of specific city labels in different academic fields; (3) which dimensions in the analysis of the smart city concept prevail in the literature; (4) what are the prospects of the utilization of the label smart city in the future. Although the literature dealing with the topic of smart cities is relatively large in the volume, the literature rarely addresses these questions, which represents one of main scientific added values of this paper. The research in the paper in methodological terms builds mainly on the content analysis approach.

\section{Literature review}

The increasing trends for urbanization and accompanying problems requires from city administrations to develop new tools and ways to manage challenges related to this new problems, including also innovative and more efficient services, increased productivity, transparency and sustainability (Albino et al., 2015; Gil-Garcia et al., 2015). This means that "smartness" is needed, when doing urban planning and policy-making, so cities responded with initiatives in this manner. These initiatives are not limited solely to city administrations, but we can observe an increased global attention to build and improve capabilities for solving new emerging problems. This is reflected also in the scientific literature, as the amount of research and, consequently, the volume of the literature on smart city related topics has increased dramatically in the last few years.

In order to cope with the challenges and also to increase competitiveness and visibility, cities, whether larger or smaller ones, started to proclaim that they either 
are, or would at least like to become, smart. It needs to be emphasized that no general consensus on what the concept of a smart city is, although Giffinger et al. (2007) have put the definition on it, and characterized a smart city well performing in a forwardlooking way regarding smart economy, smart people, smart governance, smart mobility, smart living and smart environment; and these 6 characteristics, should be built on the 'smart' combination of endowments and participatory activities of city residents. Yet, we can find also other labels or "sister" concepts that resemble to certain extent this definition, like e.g. sustainable, digital, intelligent, knowledge, resilient, creative, etc. This trend is sometimes referred to as "urban labelling" phenomenon (see Hollands, 2008), where the issue is also related to the utilization of specific labels.

Three issues are prevalent here. First, smart city concept itself has a rather fuzzy nature. For instance, Albino et al. (2015) have provided a list of more than 20 different definitions of the concept smart city, and they argue about the confusion that exists when defining other similar concepts. The lack of consensus as to the definition of a smart city has led to specific research on this topic. Namely, this research can focus either on the basic components defining the concept, either on schools of thought dealing with the conceptualization of the label, either on using the spatial approach (referencing, e.g., societal or business issues) in the conceptualization, etc. Fernandez-Anez et al. (2018) argue that particular line of the distinction is to be found between scientific and professional literature. The first one utilizes more comprehensive conceptualization, whereas the second one focuses more on the sector-specific perspective. Second, three main developmental areas of this concept exists, that is technologies, human resources and governance (Nesti, 2018), which suggest that this concept is multi-layered and multi-faceted, adding to its complexity. And third, smart city concept also tends to have a blurry line to the similar "sister" concepts, which represents a focal point of this paper.

In fact, the debate exists in the literature on the suitability of terminology utilized, combined often with the confusion when defining these sister concepts. For instance, some authors (see, e.g., Swarnalakshmi and Thanga, 2017) argue that actually smart city has numerous similar annotations, such as intelligent city, digital city, clean city, green city etc., and can thus be taken as synonyms. Similarly, Cocchia (2014) even argues that labels mean pretty much the same, as all relate to »smartness « of the city, and this might arise in the form of sustainability, digitality, intelligence, thus depending only on the meanings and understandings of different words.

In contrast, some authors (e.g., de Jong et al., 2015), argue that those categories are actually not conceptually interchangeable and that some labels or concepts are more dominant in the literature. Some concepts are narrower under what they encompass in comparison to others. Some other authors (see e.g. Ben Letaifa, 2015) have developed a hierarchy of labels and have stated that, for instance, the concept of smart city builds upon both intelligent and creative city, where the 
former is "historically" the oldest one deriving from top-down perspective and focusing on technology, whereas the later derives from bottom-up perspective, thus community-based and private sector initiatives form its core. Subsequently, smart city concept should be, for instance, a combination of both intelligent and creative city, representing balanced relationship among technology, institutions and people.

Slightly differently, Silva et al. (2018) argue that smart city concept represents an agglomerate of other various concepts that utilize ICT, like aforementioned digital city, intelligent city, sustainable city, but it is more holistic in nature. Carta (2015), in contrast, develops slightly different trajectory, where smart city concept is an upgraded version of the creative city (it could be labeled also Creative City 3.0). Interestingly, Chourabi et al. (2012) have argued that smart city concept builds mostly on intelligent and digital city concepts, which were created prior to the smart city label. Recently, scholars also started to consider the label of smart sustainable city, in order to incorporate the different aspects of sustainability in the smart city concept. A smart sustainable city is often treated as an ideological premise depending on strategic directions, where a balance between territories and human societies via ICT and behavioral changes is to be found (Garau and Pavan, 2018).

The foundations based on smartness can be found also in the recently promoted concepts of urban circular economy, circular economy in cities or simply in the label circular city. This concept has been promoted to generate prosperous and sustainable future in the cities, as cities nowadays demand almost two thirds of global energy, a half of global waste and almost 80 percent of greenhouse gas emissions. Thus, the focus is on providing policy responses for cities to cope with the above challenges (OECD, 2019). This concept basically takes smartness as an input, as the implementation demands a collaborative and science-informed decision environment, where large stakeholder involvement is advocated (Remøy et al., 2019). However, some stream of literature does not take the assumption on the linear relations among labels and concepts. Yigitcalar and Kamruzzaman (2018) argue that the link between city smartness and achieving sustainable goals is not linear, nor the impact of city smartness on the sustainable goals achievement changes over time.

Thus, the portrayed discussion suggests that these city labels are sometimes used as synonyms, also due to the fact that there is no uniform definition for the majority of labels, but sometimes they are describing and referring to different things. Moreover, the utilization of terminology is often inconsistent. These concepts share the commonality that they attempt to design and describe some roadmap for the development of the cities in the future (Gil-Garcia et al., 2015). Based on this premise, it happens quite often that these labels are used as synonyms, also due to the fact that there is no uniform definition for the majority of labels and terminology is often used inconsistently. Thus, some overlapping and cross-fertilization of the concepts has been acknowledged in the literature (de Jong et al., 2015), although 
it is evident that the label smart prevails by far, but this shift has occurred recently (Parks and Rohracher, 2019).

Namely, the majority of hits related to smart city concept correspond to the year 2015 and later. It might be argued that smart city label is the most frequently used label among other (more or less) closely related concepts, yet the time dynamics is also interesting - the popularity of this label is namely very contemporary. The label sustainable city label prevailed until 2012, after it was only surpassed by the label smart city in 2013. However, the gap between the two labels has substantially increased already in 2014, and afterwards this gap has widened even more (see WoS, 2019; Pevcin, 2019).

Thus, it is evident that there is a problem with obtaining the uniform definitions of specific labels, and also with marking distinctions among them. Moreover, the list of labels has increased in time, often reflecting the developments in academic fields and the installment of the so-called buzzwords, that sporadically become popularized. In this context, the scientific literature dealing with smart city topic and issues has received a substantial attention recently, and it has become the prevailing label when addressing contemporary urban challenges. We can identify that the majority of literature extensively deals with the role of technology in smart cities and the specific technological solutions. In fact, given the large focus of the literature on this aspects, we might even consider the label smart city as a "technical" label. The same goes with the labels like digital and intelligent city. On the other hand, labels like creative, sustainable, knowledge and resilient have more soft and social sciences related connotation, whereas labels like eco, lowcarbon and clean tend to imply more environmentalist perspective of modern cities, although the clear-cut division among the clusters might not be so straightforward (see Pevcin, 2019). This can be further supported by the results of the literature review analysis performed by Arroub et al. (2016), who have portrayed smart city literature heavily in the context of ICT's role in "smartifying" the objects, and the features of the sensing and the automation were particularly stressed.

Notwithstanding, literature has been primarily focused on the development, comparison and evaluation of different smart city rankings that have been developed in order to capture or benchmark the smartness level of particular cities under the consideration (see, e.g., Albino et al., 2015). These benchmarking comparisons show the diversity of dimensions that are taken into account and looked at (see Anthopoulos et al., 2015). Nonetheless, there is a clear lack of literature that deals with the development of city brandings through different labels. Such attempts are very rare, as for example de Jong et al. (2015), Hatuka et al. (2018) or Parks and Rohracker (2019). This paper builds on this previous approaches and further elaborates the literature on city brandings by specifically focusing on geographical and research area dimensions; and also the role of the research sponsoring and funding agencies in the promotion of city branding, in particular smart city concept, is investigated. 


\section{Methodology}

The research in the paper is based on a mixed method approach, although it builds mainly on the content analysis approach. In the first stage, the so-called manifest content analysis approach (Berelson, 1952) is utilized. The manifest type of approach has become increasingly popular in content analysis research due to the advances in methods and technology, offering higher reliability of research outputs, although it has certain limitations related to validity issues (see Dooley, 2016). The source of review data is Web of Science Core Collection (2019), which often serves as a database for scrutinizing the development of certain scientific field. This database includes global multidisciplinary information from over 18,000 journals, over 180,000 conference proceedings, and over 80,000 books, and thus often serves as a database for scrutinizing the development of certain scientific field, although it is not the only available scientific database of that kind.

Nevertheless, this database has the strongest historical coverage, it differentiates journals from other scientific outputs, and these included journals have the highest impact, if comparison is put to the Scopus and Google Scholar databases. These databases are also very stable regarding the coverage, there is a lot of overlapping, so they should not be particularly strictly differentiated (see Chadegani et al., 2013; Harzing and Alakangas, 2016). Moreover, Web of Sciences Core Collection database features more consistent coverage of journals, longer history, and an advantage in related records' analysis (Wagner, 2015). Taking this into account, the methodology utilizes only this database, given the intended specific focus on analysing historical records and journal articles.

This study focuses on the so-called manifest content approach (Berelson, 1952), which means that words or phrases are counted as they appear in the literature. We specifically focus on the topic category, which means that the appearance of specific labels is checked with the title, keywords and abstract of the paper, which represents also a potential limitation, if certain label is (deliberately, by mistake, etc.) omitted from the three, although this problem should be almost neglected as the journals are peer-review and of higher quality in this collection. In the second stage, also latent content analysis is performed, mainly with the purpose to answer the last two research question. In contrast, by endeavouring on the latent content analysis, the research is not limited solely on the contents of the one database, but it is widened, in order to facilitate all necessary elements of variable-centred approach.

We have scrutinized the appearance and frequency of the label smart city (including plural version) in the literature till the end of June 2019, where the outputs are limited to the scientific articles only, as we would like to omit the interference of irregular publication broadcasting, which occurs with conference proceedings' papers and book chapters. We have analysed the distribution of the frequency of smart city appearance in time, its geographical distribution, its relations to the 
scientific categories and research areas, the role of funding and agencies in the distribution of outputs. The comparison of the distribution of the label smart city with other "complementary" labels (i.e., sustainable city, eco city, resilient city, low-carbon city, digital city, creative city, urban circular economy/circular city) is performed. In the second stage, latent content analysis is performed around the investigation of the three main developmental areas of the smart city concept. Specifically, this research builds upon the existing endeavours in this field (e.g., de Jong et. al., 2015; Pevcin, 2019), but both complements and expands them in a sense, that it focuses also on the investigation of geographical distribution of research outputs, their categorization and area focus, notwithstanding the role of funding agencies in the research.

Finally, it needs to be stressed that this research has some limitations. It builds only on the investigation of the content of journal articles in one database, regardless of its high relevance. Moreover, the study does not focus on the analysis of specific content relationship among different labels, since this would go beyond the purposes of the research, which focuses mainly on the providing evidence on the appearance of labels in the scientific literature, taking both time as well academic discipline dimension into the account. We stress that the methodological approach utilized in the paper is mostly variable-centred case study (Yin, 2009), since we recognize that full-fledged theory is absent in the framework of this specific investigation.

\section{Empirical data and analysis}

Following, the results of the empirical investigation into WoS database are presented. Starting with the first stage of research, we present the evidence on the appearance of the label smart city in the observed database.

Table 1: The appearance of label smart city in topic category of WoS, 2013-2019

\begin{tabular}{|c|c|l|l|}
\hline Year & $\begin{array}{c}\text { Smart city } \\
\text { coverage hits }\end{array}$ & \multicolumn{1}{|c|}{$\begin{array}{c}\text { Funding agencies } \\
\text { affiliation }\end{array}$} & \multicolumn{1}{|c|}{$\begin{array}{c}\text { Geographical } \\
\text { coverage }\end{array}$} \\
\hline 2013 & 54 & 13 (NNSF China 3) & 12 USA, 10, CHN, 9 SPA \\
\hline 2014 & 138 & 18 (NNSF China 3) & 34 ITA, 23 SPA, 14 CHN \\
\hline 2015 & 316 & 40 (NNSF China 10) & 59 ITA, 51 SPA, 36 USA \\
\hline 2016 & 479 & 73 (NNSFC 25, EU 15) & 67 ITA, 64 CHN, 63 USA \\
\hline 2017 & 861 & (NNSFC 65, EU 27, NSF 14) & 128 USA, 122 CHN, 113 ITA \\
\hline 2018 & 1,123 & (NNSFC 104, EU 31, NSF 22) & 202 CHN, 186 USA, 124 ITA \\
\hline $\begin{array}{c}2019 \\
\text { (till June) }\end{array}$ & 523 & 74 (China, diverse funding) & 113 CHN, 82 USA, 47 ENG \\
\hline
\end{tabular}


The evidence presented in Table 1 suggests a rapid increase in the number of articles dealing with the topic of smart cities during the last few years in the WoS database. In 2013, only 54 articles can be traced in this database, where the topic of smart cities was clearly stated either in title, abstract and/or keywords of the article. This number has risen to 1,123 in 2018. It is also evident, if we compare the number of articles with the affiliation to the funding agencies that there has been increasing support for the research on smart city related topics also from the research funding, which suggests that smart city research is actually also a policydriven topic. For instance, in 2018 more than 100 references were given to the National Natural Science Foundation of China, and more than 30 to the European Union and European Commission funding.

In addition, the geographical coverage of the topic has changed substantially. In the period 2014-2016, the relatively largest share had Italy, but this has changed in 2017, where the USA got the relative majority, and again changing in 2018, where China become the leader. This might be attributed to the increasing support of Chinese government, also from the funding perspective, to the implementation of smart city initiatives in China (Yu and $\mathrm{Xu}, 2018)$. Thus, the rising tide of the literature relates, at least partially, to the availability of research funds, but not just in the Western world, as the increasing number of grants and funding also steams from Asian countries, like e.g. China (see WoS, 2019). Namely, if we scrutinize the acknowledgements and affiliations to the research funding, there is an increasing referencing to sponsored research, in particular to the National Natural Science Foundation of China and various funds delivered by European Union. The largest individual supporter, i.e. funding agency, of scientific articles on the topic of smart cities has been the National Science Foundation of China. Moreover, the majority of research funding attributed to smart cities has been provided through public funding. For instance, besides to the aforementioned Chinese NNSF, a handful of grants has been provided by European Union and European Commission, as well by National Science Foundation in the USA. Strikingly, this has obviously also had some effect on the geographical composition of the articles, where in 2018 China took the lead. Thus, China has become the largest provider of the scientific literature on the smart cities (see also Figure 1), judged also on the geographical coverage of articles in the WoS database. 
Figure 1: Smart city literature (articles) and geographical coverage, first ten countries

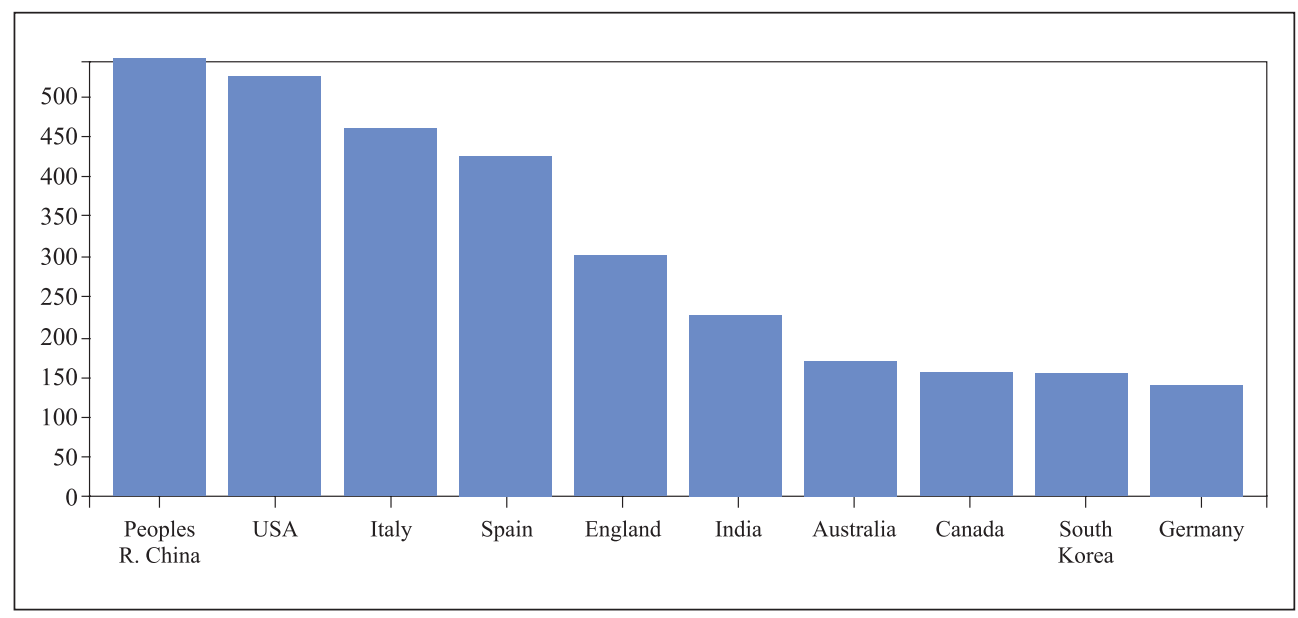

Source: WoS (2019)

The analysis continues with the frequency of specific labels' appearance in the literature. Table 2 presents the results of the analysis for 8 selected city labels, where close affiliation to the potential similarity with the smart city label was considered. Their distribution across scientific categories and research areas, main geographical distribution and main affiliation to funding agencies is also presented.

Table 2: City labels' appearance in the journals of WoS (till June 2019)

\begin{tabular}{|c|c|c|c|c|c|c|}
\hline City Label & $\begin{array}{l}\text { Total } \\
\text { number } \\
\text { of hits }\end{array}$ & $\begin{array}{l}\text { Scientific } \\
\text { category }\end{array}$ & $\begin{array}{l}\text { Research } \\
\text { area }\end{array}$ & $\begin{array}{l}\text { Number of } \\
\text { hits, yearly } \\
2017-19\end{array}$ & $\begin{array}{c}\text { Affiliation } \\
\text { to the } \\
\text { largest } \\
\text { funding } \\
\text { agency }\end{array}$ & $\begin{array}{c}\text { Geographical } \\
\text { distribution } \\
\text { (leading } \\
\text { country) }\end{array}$ \\
\hline Smart city & 3,562 & $\begin{array}{l}\text { Computer } \\
\text { Science } \\
\text { Information } \\
\text { Systems (748) }\end{array}$ & $\begin{array}{l}\text { Computer } \\
\text { Science } \\
(1,291)\end{array}$ & $\begin{array}{r}868(2017) \\
1,126(2018) \\
512(2019)\end{array}$ & $\begin{array}{l}222 \text { (NNSF } \\
\text { China) }\end{array}$ & China (561) \\
\hline $\begin{array}{l}\text { Sustainable } \\
\text { city }\end{array}$ & 1,172 & $\begin{array}{l}\text { Environmental } \\
\text { studies (274) }\end{array}$ & $\begin{array}{l}\text { Environmental } \\
\text { Sciences } \\
\text { Ecology (448) }\end{array}$ & $\begin{array}{r}185(2017) \\
218(2018) \\
94(2019)\end{array}$ & $\begin{array}{l}29 \text { (NNSF } \\
\text { China) }\end{array}$ & USA (181) \\
\hline Eco city & 274 & $\begin{array}{l}\text { Urban Studies } \\
\text { (81) }\end{array}$ & $\begin{array}{l}\text { Environmental } \\
\text { Sciences } \\
\text { Ecology (133) }\end{array}$ & $\begin{array}{l}50(2017) \\
42(2018) \\
14(2019) \\
\end{array}$ & $\begin{array}{l}15 \text { (NNSF } \\
\text { China) }\end{array}$ & China (94) \\
\hline Digital city & 192 & $\begin{array}{l}\text { Computer } \\
\text { Science Theory } \\
\text { Methods (56) }\end{array}$ & $\begin{array}{l}\text { Computer } \\
\text { Science (84) }\end{array}$ & $\begin{array}{r}19(2017) \\
21(2018) \\
9(2019)\end{array}$ & $\begin{array}{l}8 \text { (NNSF } \\
\text { China) }\end{array}$ & Japan (36) \\
\hline
\end{tabular}




\begin{tabular}{|c|c|c|c|c|c|c|}
\hline City Label & $\begin{array}{c}\text { Total } \\
\text { number } \\
\text { of hits }\end{array}$ & $\begin{array}{l}\text { Scientific } \\
\text { category }\end{array}$ & $\begin{array}{l}\text { Research } \\
\text { area }\end{array}$ & $\begin{array}{l}\text { Number of } \\
\text { hits, yearly } \\
2017-19\end{array}$ & $\begin{array}{c}\text { Affiliation } \\
\text { to the } \\
\text { largest } \\
\text { funding } \\
\text { agency }\end{array}$ & $\begin{array}{c}\text { Geographical } \\
\text { distribution } \\
\text { (leading } \\
\text { country) }\end{array}$ \\
\hline $\begin{array}{l}\text { Low-carbon } \\
\text { city }\end{array}$ & 243 & $\begin{array}{l}\text { Environmental } \\
\text { Sciences (89) }\end{array}$ & $\begin{array}{l}\text { Environmental } \\
\text { Sciences } \\
\text { Ecology (148) }\end{array}$ & $\begin{array}{l}52(2017) \\
53(2018) \\
17(2019)\end{array}$ & $\begin{array}{l}54 \text { (NNSF } \\
\text { China) }\end{array}$ & China (138) \\
\hline $\begin{array}{l}\text { Creative } \\
\text { city }\end{array}$ & 443 & $\begin{array}{l}\text { Urban Studies } \\
\text { (189) }\end{array}$ & $\begin{array}{l}\text { Urban Studies } \\
\text { (189) }\end{array}$ & $\begin{array}{l}73(2017) \\
71(2018) \\
34(2019) \\
\end{array}$ & $\begin{array}{l}5(\text { AHRC } \\
\text { UK) }\end{array}$ & $\begin{array}{l}\text { England \& } \\
\text { USA (both } \\
\text { at } 66 \text { ) }\end{array}$ \\
\hline $\begin{array}{l}\text { Smart } \\
\text { sustainable } \\
\text { city }\end{array}$ & 29 & $\begin{array}{l}\text { Green } \\
\text { Sustainable } \\
\text { Science } \\
\text { Technology (12) }\end{array}$ & $\begin{array}{l}\text { Science } \\
\text { Technology } \\
\text { Other Topics } \\
\text { (12) }\end{array}$ & $\begin{array}{l}7(2017) \\
8(2018) \\
8(2019)\end{array}$ & $\begin{array}{l}3 \\
(\mathrm{EU}+\mathrm{EC})\end{array}$ & Norway (7) \\
\hline $\begin{array}{l}\text { Resilient } \\
\text { city }\end{array}$ & 237 & $\begin{array}{l}\text { Urban Studies } \\
\text { (69) }\end{array}$ & $\begin{array}{l}\text { Environmental } \\
\text { Sciences } \\
\text { Ecology }(83)\end{array}$ & $\begin{array}{r}31(2017) \\
62(2018) \\
19(2019) \\
\end{array}$ & $7(\mathrm{EU}+\mathrm{EC})$ & USA (40) \\
\hline $\begin{array}{l}\text { Urban } \\
\text { circular } \\
\text { economy/ } \\
\text { circular city }\end{array}$ & $5 / 92$ & $\begin{array}{l}\text { Environmental } \\
\text { Sciences (2) / } \\
\text { Economics (56) }\end{array}$ & $\begin{array}{l}\text { Environmental } \\
\text { Sciences } \\
\text { Ecology (3)/ } \\
\text { Business } \\
\text { Economics } \\
(59)\end{array}$ & $\begin{array}{r}1 / 4(2017) \\
2 / 5(2018) \\
2 / 17(2019)\end{array}$ & \begin{tabular}{|l}
2 (NNSF \\
China), \\
2 (MIUR \\
Italy) / 6 \\
(NNSF \\
China), 6 \\
(Hongkong \\
RGC) \\
\end{tabular} & $\begin{array}{l}\text { Italy and } \\
\text { China (3) / } \\
\text { USA (23) }\end{array}$ \\
\hline
\end{tabular}

Source: WoS (2019), author's presentation

The results portrayed in Table 2 indicate that smart city label is the most frequently used label among other (more or less) closely related concepts or city labels, followed by labels sustainable city and creative city. Moreover, the existing evidence also reveals that the rising tide of the utilization of smart city concept can be attributed mainly to the so-called technology push, emphasizing hardware-based aspects, which can be observed also from the literature, which relates at a large margin on computer sciences. What is of interest is that the label sustainable city has more affiliations to the environmental sciences, whereas creative city to urban studies. Specifically, we can observe that smart city and digital city labels seem to have relatively more technical connotations, in contrast to other labels, which have relatively more environmental and urban connotations. Lastly, the label circular city tends to have very economic and business connotations, and as the only label among the scrutinized ones.

In the next phase, what we limit are hits to the articles in the WoS database, where labels smart city and sustainable city, either in singular or in plural form, appear in the title of the article and in the aforementioned topic category. This specific focus on these two labels steams from the fact that they are the most frequently appeared city labels in the literature, and from the relation to some previous research that has 
states that sustainable city tends to be the most frequent city label (see de Jong et al., 2015). The results of the analysis are presented in Table 3.

Table 3: The appearance of smart and sustainable city labels in article titles and topics category, 2010-2019

\begin{tabular}{|c|c|c|c|c|c|c|}
\hline & \multicolumn{3}{|c|}{ Article title appearance } & \multicolumn{3}{c|}{ Topic category appearance } \\
\hline Year & Smart city & $\begin{array}{c}\text { Sustainable } \\
\text { city }\end{array}$ & $\begin{array}{c}\text { Smart (and) } \\
\text { sustainable city }\end{array}$ & Smart city & $\begin{array}{c}\text { Sustainable } \\
\text { city }\end{array}$ & $\begin{array}{c}\text { Smart (and) } \\
\text { sustainable } \\
\text { city }\end{array}$ \\
\hline 2010 & 1 & 4 & - & 4 & 23 & - \\
\hline 2011 & 8 & 15 & - & 16 & 51 & - \\
\hline 2012 & 12 & 12 & - & 23 & 43 & - \\
\hline 2013 & 28 & 17 & - & 54 & 53 & - \\
\hline 2014 & 60 & 25 & 1 & 138 & 60 & 3 \\
\hline 2015 & 146 & 33 & 1 & 316 & 105 & 1 \\
\hline 2016 & 197 & 40 & 2 & 479 & 140 & 5 \\
\hline 2017 & 390 & 46 & 3 & 861 & 185 & 11 \\
\hline 2018 & 457 & 43 & 7 & 1,123 & 218 & 18 \\
\hline 2019 (till & 249 & 22 & 3 & 523 & 96 & 13 \\
\hline June) & & & & & & \\
\hline
\end{tabular}

Source: WoS (2019), author's presentation

For the WoS database, we find 1,552 hits where label smart city appears in the title, and 311 hits, where label sustainable city appears in the title of the article. Prior to 2010, label smart city appeared only in 4 titles (one in 1991 and 1999, and two times in 2006), whereas label sustainable city appeared in 40 titles. Nevertheless, only after 2013 the frequency of appearance changed in favour of smart city label, and it became increasingly popularized since then, and the yearly appearance of the titles has increased substantially, in particular when compared to sustainable city label, which did not receive substantial increase in the coverage. Moreover, a new label has been created, the smart sustainable city (see, e.g., Ahveniemi et al., 2017), that tries to merge the two concepts, which effectively corresponds to the notion, that label sustainable has been to some extent replaced by the label smart.

The potential reasoning behind it might be that label smart is much more politically neutral than the term sustainability, as sustainability has strong progressivists connotation which voters might not prefer. In addition, it might be also argued that in recent years there was a move from labelling digital cities as smart cities, since more focus was given to sustainability and social inclusion (Eremia et al., 2017). This suggests that smart city actually denotes sustainable city, but word smart itself is politically more acceptable. It might also denote digital city, but word smart has 
less technical connotation. In addition, the word smart refers to more instrumental concept that looks for the desired outcome, and smartness is often centred on a user perspective, and entailing strategic directions (Al-Nasrawi et al., 2015), which gives a concept a rather wise connotation, whereas sustainability refers to a more normative concept. Thus, smart city would actually mean sustainable city, but labels itself is politically more acceptable. Indeed, as Hatuka et al. (2018) have argued, smart city and other related concepts have morphed over time and have been adjusted to fit the political economies of cities, which suggests that a new concept emerges every decade.

Table 4 compares articles that have used the label smart or label sustainable city in their title or in the topic category, and relates them to geographical distribution, potential funding agencies and affiliations to research areas.

Table 4: Comparison of articles on smart and sustainable cities

\begin{tabular}{|c|c|c|c|}
\hline & Smart city & Sustainable city & $\begin{array}{l}\text { Smart (and) sustainable } \\
\text { cities }\end{array}$ \\
\hline $\begin{array}{l}\text { Total number } \\
\text { of hits - title }\end{array}$ & 1,552 & 311 & 17 \\
\hline $\begin{array}{l}\text { Research } \\
\text { areas }\end{array}$ & $\begin{array}{l}\text { Computer Science (545); } \\
\text { Engineering (374); } \\
\text { Telecommunications } \\
\text { (321); Urban Studies } \\
\text { (221); Business } \\
\text { Economics (164) }\end{array}$ & $\begin{array}{l}\text { Environmental Sciences } \\
\text { Ecology (133); Urban } \\
\text { Studies (81); Science } \\
\text { Technology Other Topics } \\
\text { (72); Public Administration } \\
\text { (42); Engineering (37) }\end{array}$ & $\begin{array}{l}\text { Science Technology } \\
\text { Other Topics (8); } \\
\text { Construction Building } \\
\text { Technology (6); Energy } \\
\text { Fuels (6) }\end{array}$ \\
\hline $\begin{array}{l}\text { Geographical/ } \\
\text { regional } \\
\text { distribution }\end{array}$ & $\begin{array}{l}\text { China (230); USA (210); } \\
\text { Italy (206), Spain (187); } \\
\text { England (143) }\end{array}$ & $\begin{array}{l}\text { USA (61); England (37); } \\
\text { Spain (18); Netherlands (16); } \\
\text { Australia, Brazil, Italy (each } \\
\text { 13) }\end{array}$ & $\begin{array}{l}\text { Norway (4); England } \\
\text { (3); Sweden (3) }\end{array}$ \\
\hline $\begin{array}{l}\text { Total number } \\
\text { of hits - topic }\end{array}$ & 3,552 & 1,118 & 51 \\
\hline $\begin{array}{l}\text { Research } \\
\text { areas }\end{array}$ & $\begin{array}{l}\text { Computer } \\
\text { Science }(1,287) ; \\
\text { Engineering }(946) ; \\
\text { Telecommunications } \\
\text { (742); Urban Studies } \\
\text { (405); Environmental } \\
\text { Sciences Ecology }(295)\end{array}$ & $\begin{array}{l}\text { Environmental Sciences } \\
\text { Ecology (450); Science } \\
\text { Technology Other Topics } \\
\text { (258); Urban Studies (242); } \\
\text { Engineering (165); Public } \\
\text { Administration (143) }\end{array}$ & $\begin{array}{l}\text { Science Technology } \\
\text { Other Topics (20); } \\
\text { Environmental Sciences } \\
\text { Ecology (14); Energy } \\
\text { Fuels (13), Construction } \\
\text { Building Technology } \\
\text { (11) }\end{array}$ \\
\hline $\begin{array}{l}\text { Geographical/ } \\
\text { regional } \\
\text { distribution } \\
\end{array}$ & $\begin{array}{l}\text { China (563); USA (529); } \\
\text { Italy (460); Spain (425); } \\
\text { England (305) }\end{array}$ & $\begin{array}{l}\text { USA (182), England (108); } \\
\text { China (99); Australia (77); } \\
\text { Spain (71) }\end{array}$ & $\begin{array}{l}\text { England (7); Norway } \\
\text { (7), Italy (6), Spain (6), } \\
\text { USA (6) }\end{array}$ \\
\hline $\begin{array}{l}\text { Funding } \\
\text { agencies } \\
\text { affiliation of } \\
\text { hits }\end{array}$ & $\begin{array}{l}\text { NNSF China (more than } \\
\text { 270); EU (more than 120); } \\
\text { NSF USA (more than 50) }\end{array}$ & $\begin{array}{l}\text { NNSF China (more than } \\
\text { 30); UK Research Councils } \\
\text { (more than 20); NSF USA }\end{array}$ & EU (5); \\
\hline
\end{tabular}

Source: WoS (2019), author's presentation 
Again, it is evident from the results presented in table 4 that label smart city has much more technical connotation that the label sustainable city, if we relate those two labels to the referenced research areas in the scientific literature. Sustainable city label is, in contrast, much more often used in environmental sciences and urban studies, and is also perceived to be used in public administration literature. Furthermore, it seems that the research focus of the articles is even increasingly becoming more focused on computer sciences, engineering and telecommunications, if we analyse the research areas, and urban studies are losing the ground. The two driving forces are evident also from the data available at Cordis (European Commission, 2019) - in FP7 framework, 207 projects were dealing with smart city issues, whereas till now Horizon 2020 framework already has allocated funding to 809 such projects, although only 24 are the ones, where domain of application is society). This corresponds to the fact that H2020 has 189 programs focusing on smart city initiatives, whereas FP7 framework had only 4 such programs.

It is evident that research funding has been one of the drivers of the growing number of publications on smart cities. Two major funding agencies are Chinese NNSF and European Union, though here the financing can be attributed to various programmes and schemes, and sometimes particular affiliations are difficult to observe or the utilization of referencing is not standardized. Nevertheless, it seems that China has the primacy in funding the research, and this has resulted also in the geographical coverage, which has since 2018 turned into its favour. What is interesting also, that label smart city has been very popular in scientific research originating in particular from Italy and Spain, if we look from the European perspective. The role of funding agencies in promoting specific terminology or label utilization can further be supported by the opposite evidence. For instance, various UK research agencies are to be found as the supporters of the research, where the focus is given to sustainable cities. This might explain, why England is having the second position within the geographical distribution of the label sustainable city.

\section{Results and discussion}

Smart city concept or label has become increasingly popular in scientific literature, and this has been a rather recent phenomenon. We might argue that the label smart city effectively acts as a replacement to the label sustainable city, which is further supported by the emergence of the new (integrated) label smart sustainable city. The replacement might be the outcome of several factors, like e.g. ideology (label smart does not have progressivists connotation, thus being more politically neutral), managerialism (smart city label refers to more instrumental concept that looks for the desired outcome, user perspective, and strategy), morphism and fatigue of old labels, etc. 
Furthermore, there has been increasing support for the research on smart city related topics also from the research funding, which suggests that smart city research is actually to some extent a policy-driven topic, and this looks like a global phenomenon, although some modest (regional and country-specific) outliers exist. Notwithstanding, at the so-called street level, the rising tide of the utilization of smart city concept can be attributed mainly to the so-called technology push. This has been explicitly revealed mainly by the critics of smart city concept, who state that prevailing understanding is too narrow, embracing only technological solutions (RolandBerger, 2017). This embracement is promoted both by business sector and political elites (see Kummitha and Crutzen, 2017; Grossi and Pianezzi, 2017), where for the later it resembles the utopian ideal solutions for the cities to be run, whereas for the former this brings potential business opportunities "sponsored" by city administrations.

Namely, Grossi and Pianezzi (2017) have argued within the framework of the socalled critical school of thought on smart city concept that smart city represents a form of technological neo-liberal utopia, where business-led technological solutions are favoured in comparison to political and long-term urban planning solutions. This critical school portrays the concept as problematic, because it is based mainly on self-proclamation and represents a cross sectional neoliberal project of influential corporations and political elite (see Kummitha and Crutzen, 2017). Similarly, Castelnovo et al. (2016) have argued that smart city concept should not be about the evaluation of the ICT and its contribution to smartness, but about generating and managing public value. However, as the technological dimensions are so heavily addressed in the literature, and this has its own volume, rebranding of the words (like e.g. digital) has enabled growing popularization and presence of the label also in the scientific literature. Thus, the first issue relates to the too extensive focus on the technological dimension of what should be understood under smart city.

RolandBerger (2017) has argued that smart city strategizing usually utilizes partial approaches, as either one dimension of "smartness" is targeted or the sector focus is narrow, where predominantly smart mobility issues are being at focus, and other "sectors" are neglected. Moreover, practical evidence even shows that the factors like the presence of ICT industry or economic attractiveness of particular city tends to represent one of the main drivers of smart city initiatives, since this requires, for example, either smart services or smart mobility (Ben Letaifa, 2015). However, there is often too much focus given to technology instead to service provision and there is a lack of coordination and planning observed, i.e. end-to-end thinking is missing. In addition, problem is often related to the narrowness of the suppliers of ICT-based solutions and insufficient understanding of the needs of the target group (RolandBerger, 2017). Thus, the second issue relates to the problems associated with lack of planning and incomplete strategies in practice when smart city initiatives are being implemented. 
The evidence also suggests that smart city is often taken as a static concept, i.e. a goal, but it should be instead considered as a process, where cities are becoming more liveable and resilient in order to be able to respond better to existing and upcoming challenges. Smart city concept should not simply represent the transactional relationship between citizens and service providers, but active participation of residents should be encouraged. Besides, leadership is also crucial, since we are bringing together hard infrastructure, human capital, institutions, and digital technologies (DBIS, 2013). Thus, it is important that citizens and other relevant stakeholders are involved into these initiatives, although such involvement might be particularly hard to achieve due to the bureaucratic reasons in less developed societies (see, e.g., Nemec et al., 2017). This reveals the problems associated with missing feedbacks and lack of co-creation and/or co-production initiatives in practice of smart city implementation.

Practical evidence on the limitations of implementation of smart city concepts indicates a very close connection to the evidence on missing literature. Namely, smart city governance literature usually tends to address issues like citizen participation, partnership, co-production of services, etc., as a backbone of governance concept, targeting value creation for society and citizens. Thus, smart city is not about technologies, but about applying new and innovative forms of governance on them to improve outcomes and processes (Pereira et al., 2018). In this context, strategy preparation and adoption are greatest challenges to effective smart city implementation, a problem further exacerbated since the governance of smart cities usually works in parallel with the existing administrative structures (Nesti, 2018). This issue relates to the necessity to create new administrative culture and new administrative structures if we want to implement smart city concept in practice.

To further support the last challenge, discussion needs to be extended. As already noted, cities as making self-proclamations also for electoral and marketing purposes. Nonetheless, these benchmarks and rankings tend to have a very important influence on the decisions of potential investors as well on city administrations to be able to judge their weaknesses and strengths, and thus form the fundaments of the city marketing strategy (Giffinger and Haindlmaier, 2010).

Furthermore, it is not just the cities that are scrutinized, but also their governments. According to the Smart Cities Study (2017) $85 \%$ of the cities have specific projects to promote smart and digital physical infrastructure, but only $60 \%$ of cities have formalized smart strategy, and the main barrier observed lies in the complexity of the existing bureaucratic processes at the various administrative levels combined with the lack of alignment between the different actors, i.e. missing coordination. This problem has also been pointed out by Meijer and Bolivar (2016), who stress the role of smart city governance, which requires smart urban collaboration between the actors in the city based upon institutional transformation. Thus, transformation 
of existing governmental structures is required, in the form of innovative ways of decision-making, innovative administration and innovative forms of collaboration. However, in practice, traditional governance of smart city existing in the form of institutional conservation can mainly be observed.

Intriguingly, the above presented results also indicate the relative advantage, at least from the perspective of the research, given to the old industrialized countries of the world. This is evident also from the international benchmarking and ranking reviews, where the cities from these countries are usually hitting the top scores. These city rankings have appeared as useful tools for comparing cities regarding their state of smart development (see, e.g., Stanković et al., 2017). Yet, the cities from the developed countries are usually hitting the top scores in those rankings. Not just the institutional and historical reasons are causing that, but also the relative advantage regarding the technological advancement and the supremacy in the level of economic development and existing financial and other resources. For the cities coming from the newly developed and emerging market countries, two dimensions that tend to be the weakest, are economy and governance, but also technology and urban planning are usually not taking the lead (see, e.g., CIMI, 2018) In particular, if we inspect the focus of the smart initiatives in the cities of Central and Eastern Europe, transportation, energy and environmental initiatives are prevailing, but these tend to be mostly technologically dominated and also financially very demanding. In this context, it is obvious that the level of economic development and the gap those cities have to the cities in the more developed regions causes that these services cannot be so extensive, and to some extent also they cannot be so advanced (Serbanica and Constantin, 2017).

Besides, Kola-Bezka et al. (2016) have pointed that cities from Central and Eastern Europe region have become involved in the smart initiatives much later than the others. This creates also different incentives for those cities, where a specific advantage of the implementation of the smart city concept may be the creation of the image of a modern and functional city, thus branding the city to encourage the inflow of new residents, investors and tourists, for which these cities are usually struggling the most. This however creates an interesting nexus. As the technology and technological solutions are prevailing usually in the initial stages of city branding, we would expect that human resources dimension and governance dimension will yet to be addressed in theory and in practice of smart city initiatives in those cities. Thus, technology is obviously the first step, but latter on the talents, people centricity, vision, policies and leadership would become much more important in the practice of smart city concepts and initiatives. Hence, this explains current focus on technological solutions and challenges.

Finally, the results presented are aligned with the findings of similar research endeavours, although different methodological approaches have been utilized in order to scrutinize the urban labelling phenomenon. As de Jong et al. (2015) have 
empirically found the supremacy of the label sustainable city persisting in the literature, Parks and Rohracher (2019) have argued that just recently the shift from sustainable to smart city has occurred, and this has been the result of appropriation and colonisation, as they have focused their analysis more on the argumentation, rather than empirical verification. Namely, the shift has been mainly discursive, and existing institutions and socio-material practices have been mainly colonized. And this adds up to the findings of Hatuka et al. (2018) also in substantive manner. This corresponds favourably also to the empirical findings presented in this study, where also historical dimension has been taken into account, and investigation has been extended to the recent time periods.

\section{Conclusion}

The intention of this paper was to address three main research questions, i.e., what has contributed to the growth of the literature on the smart cities; are there any potential patterns related to the frequency of appearance of specific city labels in different academic fields; and which dimensions in the analysis of the smart city concept prevail in the literature.

Smart city concept or label has become increasingly popular in scientific literature as well as in contemporary urban policy-making, overtaking (and substituting) some more older concepts. Besides to political neutrality of the label, an important contribution to the popularity goes to the availability of research funds, meaning that policymaking tends to drive the utilization of this concept. Nonetheless, it is still technological aspects of the topic that are prevailing in the analysis, thus issues like governance of smart cities still have potential for the upgrade.

The literature is still keeping up with synchronizing the definition of this concept, and lines are often blurred with similar "sister" concepts. Technological dimension of the smart city concept prevails both in theory as well as in urban policy-making, where technology-based initiatives are clearly having a lead. However, practical implementation of the concept generates often problems associated with lack of planning and incomplete strategies, as well as missing feedbacks of relevant actors and stakeholders. Moreover, smartness also necessitates the creation of the new administrative culture, and upgraded levels of smart city governance based upon institutional transformation.

Specifically, it is evident that the level of economic development and associated financial power of cities strongly determines the volume and intensity of smart city efforts, and thus cities from the less privileged regions in this domain have a comparative disadvantage. Furthermore, cities from these regions have become involved in smart city initiatives much later than the other cities, which generates variations also in the incentives. In this case, a specific advantage of the 
implementation of the smart city concept may be the creation of the image of a modern and functional city, so clearly more visible technological solutions are preferred, and less visible human resources and governance dimensions should be at focus later on.

Yet, city labels are actually political concepts, that dynamically accommodate their eclectic meanings in time, and every time to time some new concept emerges, the last one in line obviously being smart city concept that overpassed the sustainable city concept. This can be observed also from the publication dynamics, where the important role for the promotion of the concept builds on the availability of research funds. Thus, the question initiating from this is, whether the potential decrease in public funding on smart city related topic would decrease the volume of literature produced. The first signs of this are already starting to emerge, as the number of hits has clearly decreased in 2019 in comparison to 2018, potentially indicating also a fatigue of smart city label. Thus, city labelling can be taken a rather dynamic process, since some labels are gaining and other labels are losing their popularity in time. And new city labels might emerge also in the future, partially also to accommodate the potential necessity to achieve terminological innovativeness.

\section{References}

Ahveniemi, H., et al. (2017) "What are the differences between sustainable and smart cities?", Cities, Vol. 60, pp. 234-245.

Albino, V., Berardi, U., \& Dangelico, R.M. (2015) "Smart cities: definitions, dimensions, and performance", Journal of Urban Technology, Vol. 22, No. 1, pp. 3-21.

Al-Nasrawi, S., et al. (2015) "A conceptual multidimensional model for assessing smart sustainable cities", Journal of Information Systems and Technology Management, Vol. 12, pp. 541-558.

Anthopoulus, L.G. et al. (2015) “Comparing Smart Cities with Different Modeling Approaches". In 24th International World Wide Web Conference Committee, Florence.

Arroub, A., et al. (2016) "A literature review on Smart Cities: Paradigms, opportunities, and open problems". In 2016 International Conference on Wireless Network and Mobile Communications. Conference Proceedings, IEEE.

Ben Letaifa, S. (2015) "How to strategize smart cities: Revealing the SMART model", Journal of Business Research, Vol. 68, pp. 1414-1419.

Berelson, B. (1952) Content Analysis in Communication Research, Glencoe (IL): The Free Press.

Carta, M. (2015) “Creative City 3.0: smart cities for the urban age”. In IX. Biennial of European Towns and Town Planners: Smart planning for Europe's gateway cities. Conference proceedings. 
Castelnovo, W., et al. (2016) "Smart Cities Governance: The Need for a Holistic Approach to Assessing Urban Participatory Policy Making", Social Science Computer Review, Vol. 34, pp. 724-739.

Chadegani, A.A., et al. (2013) "A Comparison between Two Main Academic Literature Collections: Web of Science and Scopus Databases", Asian Social Science, Vol. 9, pp. 18-26.

CIMI (2018) "IESE Cities in Motion Index". Navarra: IESE Business School.

Cocchia, A. (2014) "Smart and Digital City: A Systematic Literature Review". In Dameri, R.P., \& Rosenthal-Sabroux, C. (eds.). Smart City. Basel: Springer, pp. $13-43$.

Chourabi, H., et al. (2012) "Understanding Smart Cities: An Integrative Framework". In $45^{\text {th }}$ Hawaii International Conference on System Sciences, Conference Proceedings, pp. 2289-2297.

DBIS (2013) "Smart Cities: Background Paper". London: Department for Business, Innovation and Skills.

De Jong, M., et al. (2015) "Sustainable-smart-resilient-low carbon-eco-knowledge cities: making sense of a multitude of concepts promoting sustainable urbanization", Journal of Cleaner Production, Vol. 109, pp. 25-38.

Dooley, K.J. (2016) "Using manifest content analysis in purchasing and supply management", Journal of Purchasing \& Supply Management, Vol. 22, pp. 244 246.

Eremia, M., et al. (2017) "The Smart City Concept in the 21st Century", Procedia Engineering, Vol. 181, pp. 12-19.

European Commission (2019) "Cordis" [Internet]. Available at: <https://cordis. europa.eu/en>

Fernandez-Anez, V., et al. (2018) "Smart City implementation and discourses: An integrated conceptual model. The case of Vienna", Cities, Vol. 78, pp. 4-16. Garau, C. \& Pavan, V.M. (2018) "Evaluating Urban Quality: Indicators and Assessment Tools for Smart Sustainable Cities", Sustainability, Vol. 10, No. 3 , pp. 575 (18).

Giffinger, R., et al. (2007) "Smart cities - Ranking of European medium-sized cities". Vienna: Centre of Regional Science, VTU. [Internet]. Available at: $<$ https://www.researchgate.net $>$.

Giffinger, R., \& Haindlmaier, G. (2010) "Smart cities ranking: an effective instrument for the positioning of cities?", Architecture, City and Environment, Vol. 12, pp. 7-25.

Gil-Garcia, J.R., Pardo, T.A., \& Nam, T. (2015) "What makes a city smart? Identifying core components and proposing an integrative and comprehensive conceptualization", Information Polity, Vol. 20, pp. 61-87.

Grossi, G. \& Pianezzi, D. (2017) "Smart cities: Utopia or neoliberal ideology?", Cities, Vol. 69, pp. 79-85. 
Harzing, A. \& Alakangas, S. (2016) "Google Scholar, Scopus and the Web of Science: a longitudinal and cross-disciplinary comparison", Scientometrics, Vol. 106, No. 2. , pp. 787-804.

Hatuka, T. et al. (2018) "The Political Premises of Contemporary Urban Concepts: The Global City, the Sustainable City, the Resilient City, the Creative City, and the Smart City", Planning Theory \& Practice, Vol. 19, No. 2, pp. 160-179.

Hollands, R.G. (2008) "Will the real smart city please stand up?", City, Vol. 12, pp. 303-320.

Kola-Bezka M., et al. (2016). "Smart cities in Central and Eastern Europe: viable future or unfulfilled dream?", Journal of International Studies, Vol. 9, pp. 76-87.

Kummitha, R.K.R. \& Crutzen, N. (2017) "How do we understand smart cities? An evolutionary perspective", Cities, Vol. 67, pp. 43-52.

Meijer, A., \& Bolivar, M.P.R. (2016) "Governing the smart city: a review of the literature on smart urban governance", International Review of Administrative Sciences, Vol. 82, pp. 392-408.

Nemec, J., et al. (2017) "Co-Creation as a Social Innovation in Delivery of Public Services at Local Government Level: The Slovak Experience". In Schoburgh, E. \& Ryan, R. (Eds.), Handbook of Research on Sub-National Governance and Development. Hershey: IGI Global.

Nesti, G. (2018) "Defining and assessing the transformational nature of smart city governance: Insights from four European cases", International Review of Administrative Sciences.

OECD (2019) "The Circular Economy in Cities and Regions". Paris: OECD. [Internet]. Available at: <http://www.oecd.org/cfe/regional-policy/circulareconomy-cities.htm>.

Parks, D. \& Rohracher, H. (2019) "From sustainable to smart: Re-branding or reassembling urban energy infrastructure?", Geoforum, Vol. 100, pp. 51-59.

Pereira, G.V., et al. (2018) "Smart Governance in the Context of Smart Cities: A Literature Review", Information Polity.

Pevcin, P. (2019) "The Evolution of City Labelling in the Literature", Economics \& Culture, Vol. 16, No. 1, pp. 40-45.

Remøy, H., et al. (2019) "Facilitating Circular Economy in Urban Planning", Urban Planning, Vol. 4, No. 3, pp. 1-4.

RolandBerger (2017) Smart city, smart strategy. Think: Act [Internet]. Available at: $<$ http://www.rolandberger.com>.

Serbanica, C., \& Constantin, D. (2017) "Sustainable cities in central and eastern European countries. Moving towards smart specialization", Habitat International, Vol. 68, pp. 55-63.

Silva, B.N., et al. (2018) "Towards sustainable smart cities: A review of trends, architectures, components, and open challenges in smart cities", Sustainable Cities and Society, Vol. 38, pp. 697-713. 
Smart Cities Study (2017) "International study on the situation and development of ICT, innovation and knowledge in cities". Bilbao: UCLG.

Stanković, J., et al. (2017) "A multi-criteria evaluation of the European cities' smart performance: Economic, social and environmental aspects", Zbornik radova Ekonomskog fakulteta u Rijeci, Vol. 35, No. 2, pp. 519-550.

Swarnalakshmi, R. \& Thanga, J. (2017) "Smart City Solid Waste Management Leveraging Semantic Based Collaboration". In International Conference on Computational Intelligence in Data Science. Conference proceedings.

Wagner, A.B. (2015) "A Practical Comparison of Scopus and Web of Science Core Collection”. UNY Science Librarians Meeting. [Internet]. Available at: $<$ https:// ubir.buffalo.edu/xmlui/bitstream/handle/10477/38568/Scopus\%20vs\%20WOS. pdf? sequence $=1>$

World Cities Report (2016) Urbanization and Development, Nairobi: UN-Habitat.

WoS (2019) Web of Science Core Collection. [Internet]. Available at: $<\mathrm{https} / / /$ clarivate.com>.

Zingale, N.C., et al. (2017) "Loose Governance in Action: Tinkering Around in a Shrinking City", Administrative Theory \& Praxis, Vol. 39, No. 1, pp. 32-57.

Yigitcalar, T. \& Kamruzzaman, Md. (2018) "Does smart city policy lead to sustainability of cities?", Land Use Policy, Vol. 73, pp. 49-58.

Yin, R.K. (2009) Case study research: Design and methods, 4th ed., Thousand Oaks: Sage.

Yu, W. \& Xu, C. (2018) "Developing Smart Cities in China: An Empirical Analysis", International Journal of Public Administration in the Digital Age, Vol. 5, No. 3, pp. 76-91. 


\title{
Pojam pametnog grada: prošlost, sadašnjost i budućnost ${ }^{1}$
}

\author{
Primož Pevcin ${ }^{2}$
}

\begin{abstract}
Sažetak
Koncept ili pojam pametnog grada postala je sve popularnija u znanstvenoj literaturi, kao $i$ u kreiranju suvremene urbane politike, gdje se popularizira $u$ svrhu rješavanja složenih urbanih problema. Ovaj rad usredotočuje se na pregled postojeće literature o ovom konceptu uz primjenu pristupa analize kodiranja sadržaja. Istraživanjem se potvrđuje da se u zadnje vrijeme ovaj koncept popularizira, te preuzima (i zamjenjuje) ulogu nekih starih pojmova, što bi se djelomično moglo pripisati njegovoj terminološkoj neutralnosti $i$ širem sadržaju koji pokušava obuhvatiti. Međutim, glavni praktični poticaj za njegov rast popularnosti može se pripisati tehnološkom zamahu. Sve veći broj istraživanja ovog područja djelomično odražava i dostupnost sredstava za istraživanje, što ukazuje da je istraživanje pametnih gradova također temeljeno na politici. Slijedeći ovaj trend, ne treba zanemariti potencijal za nastajanje novih oznaka gradova u budućnosti.
\end{abstract}

Ključne riječi: pametni grad, održivi grad, brendiranje grada, donošenje urbane politike

JEL klasifikacija: $031, H 83$

${ }^{1}$ Publikaciju rada omogućila je financijska podrška Slovenske istraživačke agencije (istraživački fond br. P5-0093).

2 Izvanredni profesor, Sveučilište u Ljubljani, Fakultet za javnu upravu, Gosarjeva ulica 5, SI1000 Ljubljana, Slovenia. Znanstveni interes: javni menadžment, upravljanje na više razina, lokalna samouprava.Tel.:+386_1_5805_584.E-mail:primoz.pevcin@fu.uni-lj.si. 